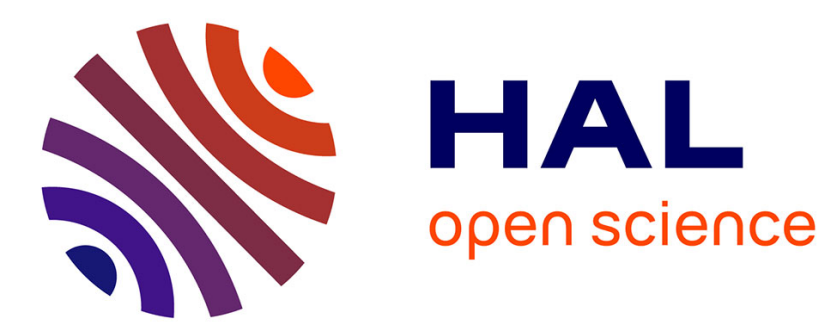

\title{
Anterior repair using Bologna procedure: long-term results on stress urinary continence.
}

\author{
Xavier * Fritel, Alain Pigné
}

\section{To cite this version:}

Xavier * Fritel, Alain Pigné. Anterior repair using Bologna procedure: long-term results on stress urinary continence.. International Urogynecology Journal, 2002, 13 (3), pp.176-81; discussion 181. inserm-00357077

\section{HAL Id: inserm-00357077 https://www.hal.inserm.fr/inserm-00357077}

Submitted on 29 Jan 2009

HAL is a multi-disciplinary open access archive for the deposit and dissemination of scientific research documents, whether they are published or not. The documents may come from teaching and research institutions in France or abroad, or from public or private research centers.
L'archive ouverte pluridisciplinaire HAL, est destinée au dépôt et à la diffusion de documents scientifiques de niveau recherche, publiés ou non, émanant des établissements d'enseignement et de recherche français ou étrangers, des laboratoires publics ou privés. 
Figure 3

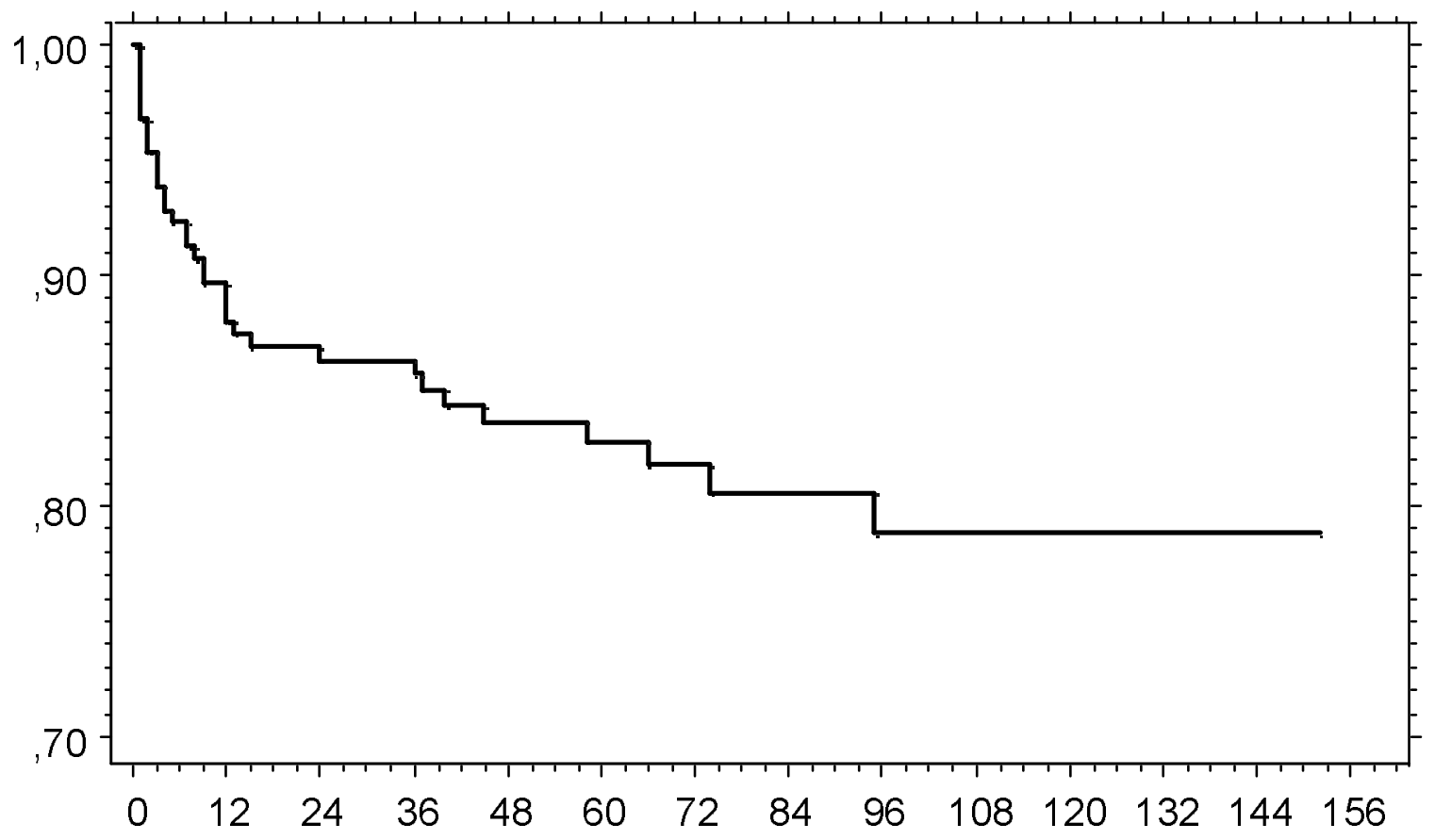

